\title{
Domestic violence through the window of the COVID-19 lockdown: a public crisis embodied/exposed in the private/ domestic sphere
}

\author{
Jane Krishnadas and Sophia Hayat Taha ${ }^{1}$
}

\begin{abstract}
COVID-19 has been recognized globally as a public health crisis, which has directly led to the deaths of more than 40,00o people in the UK (World Health Organization, 2020). The lockdown measures in the public sphere have created a window into the existing violence in the domestic sphere, as increasing incidents and reports have propelled what is more often thought of as private violence into the public gaze. The COVID-19 lockdown in the UK has made visible a collapse of the public and private sphere, blurring the boundaries between the two. As work and childcare have moved within the home, the structural inequalities of austerity have been exposed and the widening gender, class and racial cracks of society are illuminated in lockdown. Our paper draws upon an intersectional cultural and materialist analysis to explore how the cultural and economic bricks of the public and private sphere have been layered through the tools of i) representation and marginalization in the public sphere; ii) the division of labor through the devaluing of care-giving and precarious work; and iii) the location of public and private legal issues. Through this critical intersectional analysis, we explore how the material construction of the public and private sphere is being dismantled in the long-term everyday crisis interventions of domestic violence support groups, Refuge, Women's Aid and Southall Black Sisters, and in relation to the authors' local interventions with CLOCK.
\end{abstract}

Keywords: COVID-19, domestic violence in the UK, marginalization in the public sphere

\section{Introduction}

COVID-19 has been recognized by the World Health Organization as a global crisis, demanding a global response activated through public emergency health, legal, economic and social interventions. The key "protective" social intervention throughout the globe has been to encourage, demand and, indeed, legislate that families must stay at home, with people in some countries even requiring permission to go out to exercise or to support a vulnerable person. The assumption behind these social interventions is that by staying home, families will stay safe. Decisions to apply lockdowns have been actioned to safeguard the public against the spread of COVID-19. Governments have openly prioritized this public health risk over the economic risk of people losing their employment, the educational risk of children depending on home schooling, and the mental health risk of persons living in isolation at a time of heightened anxieties.

In this paper we consider how the multiple socio-economic risks created by lockdown have manifested in the rising reports of domestic violence. This is shown with a consistent increase in the demand of $45-50 \%$ for Refuge's National Domestic Abuse Helpline (Refuge.org, 2020c) and an increase spike of $950 \%$ in visits to their website (Refuge.org, 2020a). This heightened prevalence of incidents and subsequent public awareness has meant 
Vol. 7, No. 1, 46-58.

that the need for the work of organizations working at the ground level has increased. The paper argues that "domestic violence", which has systematically been marginalized within the private sphere, has inadvertently been given a public lens through COVID-19 lockdown measures, allowing the public discourse to reflect and see the cracks in relation to the everyday crisis of violence. This public lens has been made apparent through the coverage of news articles and non-governmental organizations (Archer, 2020; Grierson, 2020a; Human Rights Watch, 2020), which has amplified and revealed the everyday ongoing crisis.

The surge in reporting of domestic violence has exposed underlying historical patterns, which requires a systematic response to a systemic "problem", or rather to recognize that domestic violence is, in fact, one of the "master's tools" (Lorde, 1984) of patriarchal exploitation and oppression. Fraser notes that feminist politics, which only focus on an improvement of women's economic status or their sociocultural location are incomplete. Fraser aims to integrate and combine the two into a new conception of justice that redistributes material resources as well as sociocultural recognition (Fraser, 2013a). However, in a review of Fraser's work, a critique offered was that "it is difficult to locate how these categories hang together" (Mitchell, 2014). This paper responds to this critique by drawing upon Krishnadas' "Transformative Methodology" (Krishnadas, 2008), to interweave an analysis that links the long-term recognition and redistribution debate (Fraser and Honneth, 2003) within a critical third dimension of location; to locate an intersectional critical analysis of how patriarchy operates through the i) marginalization of women from the public sphere (Krishnadas, 2007b), ii) the exploitation of women's resources in paid and unpaid labor (Krishnadas, 2007a), and the iii) marginalization of violence as a private rather than public legal issue (Krishnadas, 2007c).

The paper will explore and question why the current government response to domestic violence through the Coronavirus Act, 2020, has been to take measures to support victims and children to "flee" violence in their home, rather than addressing the underlying gendered economic and cultural structure of the "Master's Domain", which has been exposed throughout the patriarchal response and policies. The paper draws upon the critique and interventions of domestic violence campaigners, with a focus on the work of Women's aid, Refuge, Southall Black Sisters and CLOCK, as they contribute to the ongoing work around the Domestic Abuse Bill and the public crisis that is exposed further when home is not, and has never been, a place of safety.

\section{Domestic violence (towards women) as an everyday crisis in society}

When domestic violence is seen as an everyday crisis in society, and the impact of COVID-19 is considered, we see that the pre-existing everyday crisis is heightened. Domestic violence abuse (DVA) is understood to be "any incident or pattern of incidents of controlling, coercive or threatening behaviour, violence or abuse between those aged 16 or older who are, or have been, intimate partners regardless of gender or sexual orientation". These incidents can encompass psychological, physical, sexual, economic and emotional abuse (Secretary of State for the Home Department, 2019, p. 5). DVA represents a global public health problem (WHO, 2013) and a human rights issue, impacting severely upon individuals and communities, and is estimated to have cost England and Wales $£ 66$ billion from 2016 to 2017 (Secretary of State for the Home Department, 2019).

Domestic violence affects men and women in the UK, and the context and severity of violence by men against women, and the consequent fear and sequelae for physical and mental health, therefore make domestic violence against women a much larger problem in public health terms than violence by women against men (Richardson et al., 2002). The gendered impact of domestic abuse is evident within the Office for National Statistics (ONS) statistics, which report that one in four women will be victims of domestic abuse in their lifetime (ONS, 2018) and two women a week are killed by current or former 
partners (ONS, 2018) - a statistic that has remained consistent for decades (Refuge Charity, 2019), a consistency for which the crisis of violence has become accepted in society as an everyday reality.

The everyday reality is usually an attrition of incidents forming a pattern of "coercive control" (Stark, 2009). Most singular incidents are not considered to pose an immediate risk or danger, however, this means that there are ambiguous definitions of harm, which fluctuate between different actors such as friends, family, social workers, police officers, prosecutors, judges and the victim herself (Hagemann-White, 2019, p. 155). These differing interpretations of harm and the complex context surrounding violence and abuse are also shaped by the way that the state has responded. In England and Wales domestic violence has traditionally been approached through a crime-focused lens, which prioritizes high-risk victims and shapes discussion with guidelines, checklists, Multi-Agency Risk Assessment Conferences, "duties of care", and ideas around "public protection" (Coy et al., 2011, p. 8; Robinson, 2017, p. 113). This "high risk" approach fails to identify the everyday chipping away of violence at the "lower" level, which is difficult to evidence within the reporting and court process.

It is this systematic pattern of hidden violence in the private sphere for which there has been a historical silence within the legal frameworks, domestically and internationally. The Convention against all Forms of Discrimination against Women in 1979 (UN General Assembly, 1979) did not refer to domestic violence, and it was not until 1993 that domestic violence was included in the Human Rights Conventions, and then only in the form of the Declaration against Violence Against Women (DEVAW) (OHCHR General Assembly, 1993).

The historical silence at an international level was finally broken with this critical preamble, which specifically recognized violence against women as,

a manifestation of historically unequal power relations between men and women, which have led to domination over and discrimination against women by men and to the prevention of the full advancement of women, and that violence against women is one of the crucial social mechanisms by which women are forced into a subordinate position compared with men.

(OHCHR General Assembly, 1993) Since the UK adopted the UN Violence Against Women and Children in 1993, it has taken until 2020 for the UK government to propose specific legislation: the "Domestic Abuse Bill, 2020". Finally, domestically, the government has set out, "123 commitments, both legislative and non-legislative, designed to promote awareness of domestic abuse; protect and support victims and their families; transform the justice process to prioritize victim safety and provide an effective response to perpetrators" (Domestic Abuse Bill 2020: overarching factsheet, 2020). Whilst this breaking of silence on a domestic level began before the global public health crisis, the Bill has come to be debated at the height of the COVID-19 crisis in the UK.

Public health emergencies have often illuminated the hidden everyday crisis of domestic violence. This is a repeated pattern, with past epidemics (Ebola, Zika, Cholera) showing outbreaks correlating with increased IPV and sexual violence. These outbreaks have impact through the movement restrictions and fear of infection, which intensify situations for women who are already experiencing violence (UN Women et al., 2020, p. 19). These emergencies create a global dilemma - if home is not a place of safety, is it safer to leave or stay at home?

\section{To stop the violence or to flee the home?}

Currently, with 162 countries around the world establishing "stay-at-home" orders, there are approximately 2.73 billion women impacted by "stay-at-home" orders (UN Women et al., 
Vol. 7, No. 1, 46-58.

2020, p. 19). This decision has been taken by many governments to keep people safe. Yet, the "normal" risks of domestic violence, outside of a public health crisis, mean that the home is not a safe place for many women (UN Women et al., 2020, p. 19). In the UK, following the significant rise of domestic violence reported by Refuge, Women's Aid and Southall Black Sisters (Rape Crisis England and Wales et al., 2020), the government has acknowledged that coronavirus household isolation instructions can cause anxiety for those who are experiencing or feel at risk of domestic abuse. In response, the government announced an amendment to the lockdown provisions stating that:

The government acknowledges that coronavirus household isolation instructions can cause anxiety for those who are experiencing or feel at risk of domestic abuse. There is never an excuse for domestic abuse, no matter what the circumstances are. Household isolation instructions as a result of coronavirus do not apply if you need to leave your home to escape domestic abuse.

(Home Office, 2020) This permission to "flee" resonates with the domestic individualism of the issue of domestic violence as it is presented as an external "choice" for most victims. It ignores the complexity and absolves the state from a commitment and investment to support families in crisis. It leaves the individual to be overwhelmed, knowing the risk of travelling on public transport or finding a safe home for their children where they will have the facilities for home education.

Engagement with, and demand for, assistance with domestic abuse services have drastically increased. Refuge's National Domestic Abuse Helpline has seen a " $49 \%$ increase in daily calls and contacts and $417 \%$ increase in web traffic compared to pre-lockdown averages" (Refuge Charity, 2020, p. 2). In our local project, CLOCK (the Community Legal Outreach Collaboration Keele), applications to our service have increased three-fold, receiving reports of at-risk children from our local authority, schools and GP services. Yet despite providing the assistance to seek legal representation and support to leave, our local refuge was full, and with a waiting list, in the first week of the lockdown, as acknowledged in a letter of response to our concerns by our local MP noting that:

I am aware that unfortunately as a result of the coronavirus outbreak and the lockdown restrictions there has been a rise in cases of domestic abuse. I am grateful for the work that you do as Director of the CLOCK project and I note what you say about receiving an increase in requests for assistance in response to the Newcastle-under-Lyme refuge reaching full capacity.

(Bell, 2020)

Both the local and national contexts expose to a wider audience the critical need to meet the rising demand of support for families in crisis.

Charities such as Refuge have argued that COVID-19 has further revealed the necessity of having a comprehensive government strategy to prevent abuse and support survivors, as well as enough specialist support services to meet demand (Refuge Charity, 2020). However, it is important to address the need for a comprehensive government strategy within a wider historical context of the government's marginalization of women in the public sphere. The critical question is why the government places the responsibility on women to "flee" without adequate refuge provision. Why is the emphasis not on removing the perpetrator from the "Master's House" (Lorde, 1984). This is explored by applying a "transformative methodology" (Krishnadas, 2008), through the public lens of the COVID-19 window, to analyse how women's representation has been marginalized, how women's resources are devalued and how legal issues are divided within the private sphere, developing grounded strategies to return the gaze, dismantle the public/private boundaries and reconstruct a post-COVID-19 society. 


\section{i) Marginalizing women from the public sphere}

2018 has marked continued commemorations of the 1ooth year of women being publicly endorsed as legal entities in the UK and claiming the right to vote, at which the representation of women is now at its highest, with a third of people in the House of Commons now women (Tomlin, 2020). However, the hierarchies of liberal democracy continue to privilege those often with the historical white, propertied citizenship discourses that have prevailed since the right to vote, and are masked within such policies as "No Recourse to Public Funds", which show wider models of hierarchical valuing of women's contributions to public discourse (Taha, 2019). The barriers faced by women survivors as they sought to present their evidence to the Domestic Abuse Bill also presented a significant reminder of the structural inequalities in how women may access public spaces of representation in times of crisis. The expectations to "fit" the liberal democratic model became most evident in the call of women survivors to give evidence in Parliament during the coronavirus epidemic (Grierson, 2020b). Eighteen domestic abuse and women's rights organizations wrote an open letter to the Leader of the House of Commons urging for a reconsideration of the requirement, due to the vulnerabilities witnesses had through caring responsibilities, inability to travel during lockdown, disabilities and family vulnerabilities, plus the higher risks for Black Asian Minority and Ethnic communities against COVID-19 (Women's Aid, 2020a). There has been resistance from organizations, demanding that all women are protected within the Domestic Abuse Bill (Southall Black Sisters, 2020), but it remains to be seen if these hierarchies will be deconstructed by the government.

In light of the restrictions on accessing national forums of representation, women's groups have highlighted the need for an embedded community response to collate and present evidence, where women take the lead to become "bystanders" for women experiencing domestic abuse. A report, written by Women's Aid, particularly focused upon a community response to COVID-19 and domestic abuse, asking trained community ambassadors, who work to support bystanders and the community, to recognize the signs of domestic abuse. Their community ambassadors work across 13 geographical sites throughout England and 32 of them replied to the survey conducted in April 2020.

The community ambassadors responded that they felt there was a worsening of domestic abuse and that the isolation caused by COVID-19 and "stay-at-home" orders meant that survivors had much less access to informal support networks (Women's Aid, 2020d). A second report produced by Women's Aid spoke to survivors. This report found that COVID19 not only had an impact on how survivors could access support, making it harder for them, but that perpetrators were also using COVID-19 within forms of coercive control (Women's Aid, 2020c, p. 2).

Whilst there has been an attempt to create a route to safety for women with the suggestion of a national "codeword" initiative, seen to work well in other countries, women's groups have raised serious concerns about the hidden challenges that a "codeword" initiative would bring. A joint statement on the "codeword" initiative, released by Women's Aid Federation Northern Ireland, Welsh Women's Aid, Scottish Women's Aid and Women's Aid, highlighted the need for a minimum level of mandatory training for key worker bystanders, ensuring harmful attitudes aren't within staff so that codeword responses were available to ensure Black and minoritized women, migrant women, deaf and disabled women, and LGBTQ+ survivors were reached, with a full evaluation and accountability (Angharad, 2020).

As evident within our local experiences, the difficulties in creating spaces for women to speak out about violence, whether in Parliament, the community or using codewords, depends upon the commitment to invest in and support women's resources. Without this 
Vol. 7, No. 1, 46-58.

ability to respond to women's evidence with options to leave or stay in the home safely, the lockdown has exposed the second strand of historical oppression evidence in the failure to revalue and redistribute resources in the "Master's Domain".

\section{ii) Devaluing women's resources in the public sphere}

Critical feminist literature has linked the class-based, material exploitation of women in relation to the devaluing of caregiving (Krishnadas, 2007c), the gender pay gap, and the failure to invest in services to protect and promote women from domestic violence. Olufemi argues that the "state provision, the allocation of resources and the way oversight is carried out reinforces gendered oppression by restricting women's freedom and ensuring that poor women have no means to live full and dignified lives" (Olufemi, 2020, p. 23). The UN report on gender and justice during COVID-19 documented the pre-existing conditions of Intimate Partner Violence within the discrimination of women at work and gender-based discrimination in family law:

Globally, women undertake the bulk of unpaid work and care at home, are more likely than men to work informally, part-time and in the services sector - areas of work which are often unevenly regulated and monitored, if at all, by law. The insecurity and lack of legal entitlements that characterize informal and temporary work put women and their families at extreme risk. Furthermore, unpaid work and childcare in the home has been substantially amplified with country-wide school closures in 177 countries.

(UN Women et al., 2020, p. 21) In the UK, a decade of austerity-driven cuts to legal aid and specialist services have decimated the domestic violence sector. Refuge has stated, "the current COVID-19 crisis has shone a light on the need for specialist services and Refuge is hopeful that the Government will move quickly to implement its commitment to a legal duty to fund refuges with enough funding to ensure that no women or child is ever turned away" (Refuge.org, 202ob). There is a need for the government to give real material resources to specialist services, both as a reaction to COVID-19 and as a general commitment to women's safety. Women's Aid conducted a survey of their 45 local domestic abuse services covering all regions of England. They found that $84.4 \%$ of respondents had to reduce or cancel services due to COVID-19 (Women's Aid, 202ob, p. 3). They also found that only 30.3\% of the responding refuges had adequate PPE for their staff (Women's Aid, 202ob, p. 4). Services also raised the issues of the challenges staff have faced working remotely, both due to childcare and lack of privacy to continue client work, and their own personal anxieties that their clients are not getting enough support (Women's Aid, 202ob, pp. 7-8) . Their report also found that there was a $37 \%$ spike in self-referrals in the days leading to national lock down, which has since at the time of the survey (6th April 2020) plummeted, indicating women are unable to seek support now that they are staying at home.

Finally, services reported concerns about loss of funding and being unable to cover costs for their services; "By running DA services close to the bone we have not left any resilience for times like this” (Women's Aid, 202ob, p. 11). Resources for women's basic needs are not valued by the state. As Olufemi notes, "When successive governments implement violent austerity policies in order to 'balance the budget', it is women who are hit the hardest, because their lives have always been intimately linked to the state" (Olufemi, 2020, p. 25).

A joint initiative between housing providers and refuges found that the pandemic has meant resettlement is harder, which means refuges are blocked for other survivors who need to escape; "The average number of refuge vacancies in England during the first 7 weeks of lockdown was 97 , compared with an average of 183 for the same period in 2019" 
(The Domestic Abuse Housing Alliance et al., 2020, p. 2). The reduction of refuge spaces at a point of crisis has provided further evidence of the violence from the state, who have avoided responsibility for women, leaving them with no "choice" other than to stay within violent homes.

\section{iii) Marginalization of violence as a private rather than public legal issue}

It is this marginalization of women within the home that highlights the third layer of patriarchy, for which it is important to understand how the "Masters' Domain" has been constructed in both the seclusion of the nuclear unit family and the exclusion of others, as Barret and McIntosh note: "The exclusion of outsiders and turning in to the little family group may seem attractive when it works well and when the family does satisfy its members' needs. But the little enclosed group can also be a trap, a prison whose walls and bars are constructed of the ideas of domestic privacy and autonomy" (Barrett and McIntosh, 2015, p. 56). In a recent news article, Rob Merrick has noted the "Glaring holes" in the Domestic Abuse Bill, which mean that "women will still have no escape route from violence, or being killed" (Merrick, 2020). Merrick's article warns that there are still many gaps within the Domestic Abuse Bill, with those that turn to community health services, migrant women and women who are stalked at work still facing little support (Merrick, 2020).

There has been a call from multiple women's groups for more investment in services, better protection for women at work, an end to the NRPF policy so that migrant women can access refuges, and a requirement for health and community services to be supported in providing or signposting refuge spaces for women, and yet, the legal constructions of domestic violence as a public or private issue has led to distinct (and still inadequate) responses, which the Domestic Abuse Bill is supposed to address. It has been proposed to bridge the gap, and yet it is evident that the bridge may become a dam, as the Family Court is overflowing with a backlog of private law family cases for which the President has noted in the COVID-19 period:

It is well known that, prior to COVID-19, the Family Court was already attempting to process an unprecedented level of applications relating to children. Applications for domestic abuse injunctions have either remained at usual levels or have, in certain inner-city areas, significantly risen. It is anticipated that, once social services are able to function more normally and once more children come out of lockdown and return to school, the volume of child protection cases may surge.

(Sir Andrew McFarlane, 2020)

The reality is that the courts are now faced with trying to deliver fair, just and timely responses that support women and families with a drastically reduced set of resources and using remote systems. The public and private barriers to access to justice are highest in relation to the status of migrant women, who have been categorically labelled outside the public sphere, with "No Recourse to Public Funds" to access legal proceedings or a place of refuge.

The COVID-19 crisis has served to demonstrate just how precarious the position of migrant survivors is . . Many migrant survivors who were working and were able to maintain some economic independence have lost their jobs due to the ongoing crisis . . However, unlike the millions of people who have made a Universal Credit claim over the past few weeks, migrant survivors do not have this option, leaving many trapped with abusers.

(Refuge Charity, 2020, p. 6) This loss of temporary safety from being in a place of work, and the loss of financial independence shows how migrant women with NRPF are frequently endangered by the immigration status forced upon them. The provisions to help migrant women seek help in the 
Vol. 7, No. 1, 46-58.

case of domestic abuse are not adequate outside of a public health crisis. The "NRPF" status's unsuitability and lack of protection for migrant women has been fully exposed in the public sphere during COVID-19.

\section{Dismantling the master's tools: intersectional and community-based resistance}

Whilst a report from UN Women has noted the unprecedented disruption to not only the ways that people live and work, but also to the delivery of public services, including justice, due to COVID-19 (UN Women et al., 2020, p. 13), in the UK, we have already been in a state of crisis for some time. There has been the need to develop emergency strategies as a direct response to the crisis of austerity cuts to legal aid, creating unprecedented barriers to access to justice. The Community Legal Outreach Collaboration, Keele (CLOCK) was initiated in 2012 to respond to "community unmet legal needs", directly informed by research with "Voices of Experience" of women in a local domestic violence refuge who shared the complexities of their needs across the criminal and family court, welfare, housing and health sectors (Voices of Experience, 2020), in light of the significant withdrawal of legal aid through LASPO (The Legal Aid, Sentencing and Punishment of Offenders Act 2012, 2013).

Access to justice is often framed in the language of "complex needs", which has been pivotal since the NHS and Community Care Act 1990, which was meant to ensure that services worked to respond and align with an individual's needs. However, the reality is that the notion of "need" is framed with ideas of financial resources, allocating and rationing, and controlling who is helped according to a risk analysis (Godfrey and Callaghan, 2000, p. 1; Harris and Hodges, 2019, p. 168). Drawing upon women's Voices of Experience, CLOCK has applied a "Transformative Methodology" (Krishnadas, 2018) to centre their experience and inform how to access a range of services in family law, housing, welfare, health and safety. The CLOCK students are trained to signpost to legal aid and charitable support and, where not available, to apply for Exceptional Case Funding, or to assist within the remit of the McKenzie Friend principles (Lord Neuberger of Abbotsbury, Master of the Rolls and Sir Nicholas Wall, President of the Family Division, 2010). This intersectional and community-based strategy works to respond to the everyday reality of individuals, who all have "complex" needs.

COVID-19 has meant that community-based strategies have had to rapidly change and re-think how they help women. On March 16th, 2020, following guidance from our Designated Family Judge, we closed the CLOCK court desk to reduce any risk to court users, following which the court officially closed on March 23rd. Since then the Court has adopted a range of remote strategies to support the most urgent cases involving risk to children, for which CLOCK has developed online reporting and monitoring systems to ensure requests for assistance are met through the collaboration of online services to reach out to those in need within their homes.

There have also been movements to ensure that women who need to access support digitally can do so without having to pay data charges ("National Domestic Abuse Helpline website to be accessible free of data charges", 2020). A further innovation is the use of a disguised free app called "Bright Sky", which signposts to support, has a journal function to track incidents of abuse and an emergency button that calls 999 (UN Women et al., 2020, p. 28). Additionally, Cumbria Police launched a campaign to work with postal workers, delivery drivers, food delivery companies, and anyone who was still visiting homes, to look out for signs of abuse and report them to the police (UN Women et al., 2020, p. 28). CLOCK has responded to the call to adopt alternative online assistance through strengthening the clock.uk.net system as a collaboration of public, private and charitable organizations to support families in crisis. The role of the Community Legal Companion was envisaged to 
share the journey through the legal system as, in light of the above discussion, it is critical that on identifying and reporting such violence there is support and a safe place to go to. All these community responses to COVID-19 have provided the chance for women to knock at the window, to seek support, and for support to be delivered online to women within their homes.

In each of the scenarios there is now a public call - not to look away from what has traditionally been seen as a "domestic" situation but to actively encourage the public to look through the windows to identify and support women to report domestic violence. Critically, the role of identifying, monitoring and reporting is to collaboratively dismantle the patriarchal tools and reconstruct a post-COVID-19 society that is community led.

\section{Conclusion: reconstructing a post-COVID-19 society}

COVID-19 has presented a global realization that an individual's action can impact the wider public's safety, shattering the patriarchal myth of autonomy (Fineman, 2005). This truth exemplifies the feminist principles of a collective society, that we are critically interlinked and interdependent. The lessons of a public health crisis, which have informed health and economic policies, now need to be embedded to inform the long-term historic crisis of the underlying risks to health, wellbeing and lives, of liberal, individualized and fragmented structures. In this paper we call for a close engagement with feminist critical literature, which has highlighted the unsustainability and harms of a patriarchal and capitalist society for which the division of the public and private sphere has fragmented and exploited women and created significant risks to children. As Fraser notes, feminism's earlier concern that "focuses upon class inequality may not have seen 'non-economic' injustices as domestic violence" (Fraser, 2013b), have now been exposed through the increasing intersectional approach, drawing together the solidarity of cultural and material perspectives of "Feminism for the 99\%", which mobilizes Black and brown women, cis and trans women, bi and lesbian women, workers of the poor and the low waged, of unpaid caregivers, of sex workers and migrants (Arruzza, Bhattacharya and Fraser, 2019).

As authors, we have drawn upon our long-term engagement with Fraser's cultural and material debates to create and apply an intersectional and transformative approach (Krishnadas, 2018) to address the fundamental and systematic social mechanism of how violence, seen through the silencing of women's voices, devaluation of women's labor, and location of women's lives across the public and private sphere, is exercised within society. We propose that interventions from community-based actions, and the strengthening of solidarity-building approaches, act to redress these issues and resist the systematic violence from the state. We propose that by re-routing the public gaze we can dismantle the layers of patriarchy and reconstruct, through the reflection of women's political participation, the revaluation of women's resources and the relocation of women's engagement across the public and private sphere, towards an equitable and healthy post-COVID-19 society.

\section{Note}

${ }^{1}$ Dr Jane Krishnadas is a Senior Lecturer in Law at Keele University and the Convenor of the Community Legal Outreach Collaboration Keele, clock.uk.net, which is an innovative application of her "Transformative Methodology" (2008) to create an intersectional and collaborative mechanism of the public, private and third sector for access to justice.

Sophia Hayat Taha is a British-Lebanese ESRC funded NWSSDTP PhD candidate at Keele University. Her PhD uses an interdisciplinary approach combining Law and International Relations to allow for a different understanding of how the state interacts with migrant women, moving away from a Eurocentric interpretation of law. Orcid ID is: https://orcid.org/oooo-0oo3-0177-1862 


\section{Bibliography}

Angharad (2020) 'Joint statement on codeword scheme', Women's Aid, 22 May. Available at: https://www.womensaid.org.uk/joint-statement-on-codeword-scheme/ (Accessed: 8 June 2020).

Archer, N. (2020) 'The COVID-19 domestic violence crisis in the UK is a decade in the making', openDemocracy. Available at: https://www.opendemocracy.net/en/5050/covid-19-domesticviolence-crisis-uk-decade-making/ (Accessed: 7 July 2020).

Arruzza, C., Bhattacharya, T. and Fraser, N. (2019) Feminism for the 99\%: A Manifesto. London, UK: Verso.

Barrett, M. and McIntosh, M. (2015) The Anti-social family. 2nd edn. London, UK: Verso.

Bell, A. (2020) 'Letter from Aaron Bell MP for Newcastle-Under-Lyme Re: Domestic Abuse Ref: AB3477 sent to Dr Jane Krishnadas 1oth July 2020'.

Coy, M. et al. (2011) 'Roads to Nowhere? Mapping Violence Against Women Services', Violence Against Women, 17(3), pp. 404-425. doi: 10.1177/1077801211398637.

Domestic Abuse Bill 2020: overarching factsheet (2020) GOV.UK. Available at: https://www. gov.uk/government/publications/domestic-abuse-bill-2020-factsheets/domestic-abusebill-2020-overarching-factsheet (Accessed: 6 July 2020).

Fineman, M. A. (2005) The Autonomy Myth A Theory of Dependency. New York: The New Press.

Fraser, N. (2013a) Fortunes of Feminism: From State Managed Capitalism to Neoliberal Crisis. London, UK: Verso.

Fraser, N. (2013b) 'How feminism became capitalism's handmaiden - and how to reclaim it', The Guardian, 14 October. Available at: https://www.theguardian.com/commentisfree/2013/ oct/14/feminism-capitalist-handmaiden-neoliberal (Accessed: 13 July 2020).

Fraser, N. and Honneth, A. (2003) Redistribution or Recognition? A Political-Philosophical Exchange. Translated by J. Golb, J. Ingram, and C. Wilke. London, UK: Verso.

Godfrey, M. and Callaghan, G. (2000) Exploring unmet need.UK:Joseph Rowntree Foundation, p. 30. Available at: https://www.jrf.org.uk/sites/default/files/jrf/migrated/files/184263150o. pdf (Accessed: 6 July 2020).

Grierson, J. (2020a) 'Domestic abuse killings “more than double” amid Covid-19 lockdown', The Guardian, 15 April. Available at: https://www.theguardian.com/society/2020/apr/15/ domestic-abuse-killings-more-than-double-amid-covid-19-lockdown (Accessed: 7 July 2020).

Grierson, J. (2020b) 'Survivors of domestic abuse told to give evidence in person at Commons', The Guardian, 28 May. Available at: https://www.theguardian.com/society/2020/may/28/ survivors-of-domestic-abuse-told-to-give-evidence-in-person-at-commons (Accessed: 6 July 2020).

Hagemann-White, C. (2019) 'Redress, rights and responsibilities: comparing European intervention systems', Journal of Gender-Based Violence, 3(2), pp. 151-165. doi: https://doi.org/10. 1332/239868019X15538586416633.

Harris, L. and Hodges, K. (2019) 'Responding to complexity: improving service provision for survivors of domestic abuse with "complex needs"', Journal of Gender-Based Violence, 3(2), pp. 167-184. doi: 10.1332/239868019X15538587319964. 
Home Office (2020) Domestic abuse: get help during the coronavirus (COVID-19) outbreak, GOV.UK. Available at: https://www.gov.uk/guidance/domestic-abuse-how-to-get-help (Accessed: 6 July 2020).

Human Rights Watch (2020) UK Failing Domestic Abuse Victims in Pandemic, Human Rights Watch. Available at: https://www.hrw.org/news/2020/o6/o8/uk-failing-domestic-abusevictims-pandemic (Accessed: 7 July 2020).

Krishnadas, J. (2007a) 'Global de-valuing of local capacities to care: from rights of redistribution to revaluation in the post-earthquake reconstruction process, Maharashtra legal constructions of unpaid caregiving', Northern Ireland Legal Quarterly, (3), pp. 376-394. Available at: https://heinonline.org/HOL/P?h=hein.journals/nilq58\&i=382.

Krishnadas, J. (2007b) 'Identities in reconstruction: from rights of recognition to reflection in post-disaster reconstruction processes', Feminist Legal Studies, 15(2), pp. 137-165. doi: 10.1007/s10691-007-9054-1.

Krishnadas, J. (2007c) 'Relocating the Master's Domain: social and legal locations of gender from post-disaster to everyday life', Social E Legal Studies, 16(1), pp. 131-147. doi: 10.1177/0964663907073778.

Krishnadas, J. (2008) 'Rights as the intersections: rebuilding cultural, material and spatial spheres, a transformative methodology', in Dasgupta, R. (ed.) Cultural Practices, Political Possibilities. UK: Cambridge Scholars Publishing.

Krishnadas, J. (2018) 'CLOCK “The Community Legal Companion” as an Agent of Change: A Transformative Methodology', in Reimagining Clinical Legal Education. Oxford: Hart Publishing.

Lord Neuberger of Abbotsbury, Master of the Rolls and Sir Nicholas Wall, President of the Family Division (2010) Practice Guidance: McKenzie Friends (Civil and Family Courts). UK: Judiciary UK, p. 5. Available at: https://www.judiciary.uk/wp-content/uploads/JCO/ Documents/Guidance/mckenzie-friends-practice-guidance-july-2010.pdf (Accessed: 6 July 2020).

Lorde, A. (1984) 'The master's tools will never dismantle the master's house', in Sister Outsider: Essays and Speeches. 2007th edn. Berkeley, CA: Crossing Press, pp. 110-114.

Merrick, R. (2020) 'Domestic Abuse Bill: Glaring holes mean women will still have no escape route from violence, campaigners say', The Independent. Available at: https://www.independent.co.uk/news/uk/politics/domestic-abuse-bill-commons-violence-deaths-jess-phillips-a9600396.html (Accessed: 6 July 2020).

Mitchell, M. E. (2014) 'Fortunes of Feminism: From State-Managed Capitalism to Neoliberal Crisis' reviewed by $M$ E Mitchell, Marx E Philosophy Review of Books. Available at: https:// marxandphilosophy.org.uk/reviews/7852_fortunes-of-feminism-review-by-m-e-mitchell/ (Accessed: 13 July 2020).

'National Domestic Abuse Helpline website to be accessible free of data charges' (2020) Refuge Charity - Domestic Violence Help, 11 June. Available at: https://www.refuge.org.uk/ data-free-website-access/ (Accessed: 17 June 2020).

OHCHR General Assembly (1993) OHCHR | Declaration on the Elimination of Violence against Women. Available at: https://www.ohchr.org/en/professionalinterest/pages/violence againstwomen.aspx (Accessed: 3 July 2020).

Olufemi, L. (2020) Feminism, Interrupted Disrupting Power. London, UK: Pluto Press. 
Vol. 7, No. 1, 46-58.

ONS (2018) Domestic abuse: findings from the Crime Survey for England and Wales: year ending March 2018. UK: Office of National Statistics. Available at: Domestic abuse: findings from the Crime Survey for England and Wales: year ending March 2018'. Available at: https:// www.ons.gov.uk/peoplepopulationandcommunity/crimeandjustice/articles/domesticabuse findingsfromthecrimesurveyforenglandandwales/previousReleases (Accessed: 29 June 2020).

Rape Crisis England and Wales et al. (2020) 'Joint Open Letter to Prime Minister Re: Covid19 pandemic and preventing and responding to an increase in violence against women and girls'. Available at: https://www.womensaid.org.uk/covid-19-an-open-letter-to-the-primeminister/.

Refuge Charity (2019) Draft Domestic Abuse Bill 2019 joint scrutiny committee - Refuge evidence submission. London, UK, p. 22. Available at: https://www.refuge.org.uk/policyconsultations/ (Accessed: 17 June 2020).

Refuge Charity (2020) Refuge briefing: Domestic Abuse Bill 2020 second reading, Refuge priorities April 2020. UK: Refuge Charity, p. 8. Available at: https://www.refuge.org.uk/policyconsultations/ (Accessed: 17 June 2020).

Refuge.org (2020a) Nationaldahelpline. Available at: http://www.nationaldahelpline.org.uk/ (Accessed: 6 July 2020).

Refuge.org (2020b) 'Refuge responds to the second reading of the Domestic Abuse Bill', Refuge Charity - Domestic Violence Help, 28 April. Available at: https://www.refuge.org. uk/refuge-responds-to-the-second-reading-of-the-domestic-abuse-bill/ (Accessed: 17 June 2020).

Refuge.org (2020c) 'Refuge response to Home Affairs Select Committee report on domestic abuse during Covid-19', Refuge Charity - Domestic Violence Help, 27 April. Available at: https://www.refuge.org.uk/refuge-response-to-home-affairs-select-committee-report-ondomestic-abuse-during-covid-19/ (Accessed: 17 June 2020).

Richardson, J. R., Feder, G. and Coid, J. (2002) 'Domestic abuse is a gendered crime', British Medical Journal. Available at: https://www.womensaid.org.uk/information-support/whatis-domestic-abuse/domestic-abuse-is-a-gendered-crime/.

Robinson, A. J. (2017) 'Domestic violence and abuse in the UK', in Buzawa, E. and Buzawa, C. (eds) Global Responses to Domestic Violence. Cham, CH: Springer, pp. 107-124.

Secretary of State for the Home Department (2019) Transforming the Response to Domestic Abuse Consultation Response and Draft Bill. Government Website. UK: HM Government, p. 196. Available at: https://www.gov.uk/government/publications/domestic-abuse-consultationresponse-and-draft-bill (Accessed: 6 July 2020).

Sir Andrew McFarlane (2020) Message from the President of the Family Division: Private Law Working Group Report, Courts and Tribunals Judiciary. Available at: https://www.judiciary. uk/announcements/message-from-the-president-of-the-family-division-private-law-workinggroup-report/ (Accessed: 6 July 2020).

Southall Black Sisters (2020) 'Domestic Abuse Survivors urge MPs to protect all victims equally', Southall Black Sisters, 4 June. Available at: https://southallblacksisters.org.uk/ news/domestic-abuse-survivors-urge-mps-to-protect-all-victims-equally/ (Accessed: 9 June 2020).

Stark, E. (2009) Coercive Control: How Men Entrap Women in Personal Life (Interpersonal Violence). 1st edn. Oxford University Press, U.S.A. 
Taha, S. (2019) Intersectional Needs OfMigrant Women E The Impact OfNRPF: A Postcolonial Feminist Exploration. MRes Dissertation. Keele University.

The Domestic Abuse Housing Alliance et al. (2020) Housing Providers E Refuges: Tackling move-on together during COVID 19. Call to Action, p. 3. Available at: https://www.crisis.org. uk/media/242263/standing-together.pdf (Accessed: June 2020).

The Legal Aid, Sentencing and Punishment of Offenders Act 2012 (2013). Queen's Printer of Acts of Parliament. Available at: http://www.legislation.gov.uk/uksi/2013/77/made (Accessed: 6 July 2020).

Tomlin, S. (2020) '50:50 Part of Equal Power!', 50:50 Parliament, 14 January. Available at: https://505oparliament.co.uk/introducing-equal-power/ (Accessed: 6 July 2020).

UN General Assembly (1979) Convention on the Elimination of All Forms of Discrimination against Women, UN Women. Available at: https://www.un.org/womenwatch/daw/cedaw/ (Accessed: 6 July 2020).

UN Women et al. (2020) Justice for Women Amidst COVID-19. New York: UN Women, IDLO, UNDP, UNODC, World Bank and The Pathfinders. Available at: https://www.undp.org/ content/undp/en/home/librarypage/womens-empowerment/justice-for-women-amidstcovid-19.html (Accessed: 30 May 2020).

Voices of Experience (2020) Voices of Experience. Available at: https://voices-architecture. com (Accessed: 6 July 2020).

WHO (2013) WHO Violence against women: a 'global health problem of epidemic proportions', World Health Organization. Available at: https://www.who.int/mediacentre/news/ releases/2013/violence_against_women_20130620/en/ (Accessed: 6 July 2020).

Women's Aid (2020a) 'Government urged to reconsider requirement for survivors to attend parliament in person', Womens Aid, 26 May. Available at: https://www.womensaid.org.uk/ government-urged-to-reconsider-requirement-for-survivors-to-attend-parliament-in-person/ (Accessed: 8 June 2020).

Women's Aid (2020b) 'The impact of Covid-19 on domestic abuse support services: findings from an initial Women's Aid survey', Women's Aid. Available at: https://www.womensaid. org.uk/research-and-publications/evidence-briefings-the-impact-of-covid-19-on-survivorsand-services/ (Accessed: 8 June 2020).

Women's Aid (2020c) 'The impact of Covid-19 on survivors: findings from Women's Aid's initial Survivor Survey', Women's Aid. Available at: https://www.womensaid.org.uk/researchand-publications/evidence-briefings-the-impact-of-covid-19-on-survivors-and-services/ (Accessed: 8 June 2020).

Women's Aid (2020d) 'The importance of a tested community response to domestic abuse and the impact of the Covid 19 pandemic', Women's Aid. Available at: https://www. womensaid.org.uk/research-and-publications/evidence-briefings-the-impact-of-covid19-on-survivors-and-services/ (Accessed: 8 June 2020).

World Health Organization (2020) The United Kingdom: WHO Coronavirus Disease (COVID19) Dashboard, World Health Organisation. Available at: https://covid19.who.int (Accessed: 6 July 2020). 